\title{
PENGARUH KUALITAS SISTEM, KUALITAS INFORMASI, DAN KUALITAS LAYANAN TERHADAP PENGGUNAAN SISTEM E-LEARNING DI PROGRAM PASCASARJANA UNIVERSITAS MERCU BUANA
}

\author{
Purwanto S.K \& Suharno Pawirosumarto \\ Program Pascasarjana Universitas Mercu Buana Jakarta \\ E-mail: purwanto@mercubuana.ac.id,suharno@mercubuana.ac.id
}

\begin{abstract}
This study aims to determine and analyze the use of e-learning system Master of Management Program. Population in this research is student of system elearning system of Management Master Degree Program of 2014. The method in this research is quantitative research, done by using statistical procedure to draw conclusion or hypothesis testing. Analytical methods used GSCA (Generalized Structured Component Analysis). Stages of activities undertaken are: (1) designing structural models; (2) designing the measurement model; (3) construct path diagrams; (4) the conversion of path diagrams to the system of equations; (5) estimates; (6) evaluation of goodness of FIT; And (7) hypothesis testing. The result of the research shows that the quality of the system influences and signifies the usage, (2) the quality of the information influences and significant to the usage, and (3) the quality of service influences and significant to the usage.
\end{abstract}

Keywords: system quality, information quality, quality of service, and use

\begin{abstract}
Abstrak: Penelitian ini bertujuan untuk mengetahui dan menganalisis penggunaan sistem e-learning Program Studi Magister Manajemen. Populasi dalam penelitian ini adalah mahasiswa pengguna sistem e-learning Program Studi Magister Manajemen angkatan 2014. Metode dalam penelitian ini adalah penelitian kuantitatif, dilakukan dengan menggunakan prosedur statistik untuk menarik simpulan atau pengujian hipotesis. Metode analisis yang digunakan GSCA (Generalized Structured Component Analysis). Tahapan kegiatan yang dilakukan adalah: (1) merancang model structural; (2) merancang model pengukuran; (3) mengkontruksi diagram jalur; (4) konversi diagram jalur ke sistem persamaan; (5) estimasi; (6) evaluasi goodness of FIT; dan (7) pengujian hipotesis. Hasil penelitian menunjukkan bahwa kualitas sistem berpengaruh dan signigfikan terhadap penggunaan, (2) kualitas informasi berpengaruh dan sigifikan terhadap penggunaan, serta (3) kualitas layanan berpengaruh dan signifikan terhadap penggunaan.
\end{abstract}

Kata kunci : kualitas sistem, kualitas informasi, kualitas layanan, dan penggunaan

\section{PENDAHULUAN}

Perkembangan dan kemajuan teknologi memberikan pengaruh yang cukup besar terhadap perkembangan dalam bidang informasi. Saat ini, informasi menjadi kunci terpenting dalam kehidupan manusia. Pengaruh perkembangan dan penerapan teknologi informasi dan komunikasi tersebut juga sampai ke berbagai aspek lain di pendidikan salah satunya, teknologi menghadirkan media pembelajaran baru. Sebagai produk dari sebuah 
kebudayaan, teknologi sudah merupakan bagian integral dan tak terpisahkan dengan kehidupan masyarakat moderen.

Perkembangan dan penggunaan teknologi di Indonesia menunjukkan tren yang semakin meningkat, salah satu sarana pengguna teknologi di Indonesia adalah internet. Data dari emarketer.com, Indonesia saat ini berada pada peringkat ke-enam jumlah pengguna internet dengan data sebagai berikut:

Tabel 1. Pengguna dan Prediksi Pengguna Internet di Indonesia

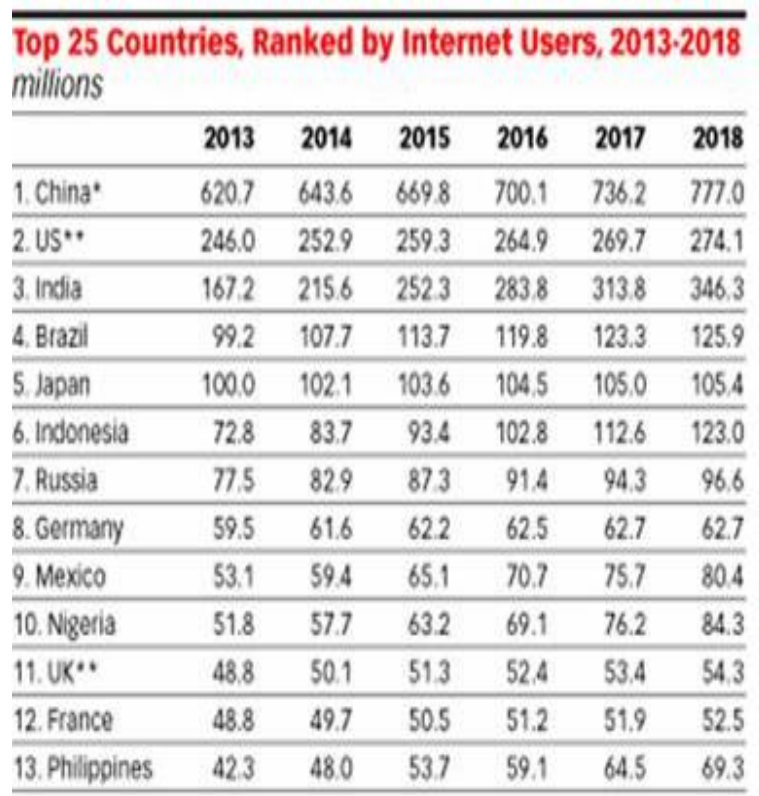

\begin{tabular}{|c|c|c|c|c|c|c|}
\hline 14. Turkey & 36.6 & 41.0 & 44.7 & 47.7 & 50.7 & 53.5 \\
\hline 15. Vietnam & 36.6 & 40.5 & 444 & 48.2 & $\$ 2.1$ & 55.8 \\
\hline 16. South Korea & 40.1 & 40.4 & 40.6 & 40.7 & 40.9 & 41.0 \\
\hline 17. Egypt & 34.1 & 360 & 38.3 & 40.9 & 43.9 & 47.4 \\
\hline 18. Italy & 34.5 & 35.8 & 36.2 & 37.2 & 37.5 & 37.7 \\
\hline 19. Spain & 30.5 & 31.6 & 323 & 33.0 & 33.5 & 33.9 \\
\hline 20. Canada & 27.7 & 28.3 & 28.8 & 29.4 & 29.9 & 30.4 \\
\hline 21. Argentina & 25.0 & 27.1 & 29.0 & 29.8 & 30.5 & 31.1 \\
\hline 22. colombia & 24.2 & 26.5 & 28.6 & 29.4 & 30.5 & 31.3 \\
\hline 23. Thailand & 22.7 & 243 & 26.0 & 27.6 & 29.1 & 30.6 \\
\hline 24. Poland & 22.6 & 22.9 & 23.3 & 23.7 & 24.0 & 24.3 \\
\hline 25. South Africa & 20.1 & 22.7 & 25.0 & 27.2 & 29.2 & 30.9 \\
\hline Worldwide:" & 92.9 & 2.892 .7 & $3,072.6$ & $3,246.3$ & $3,419.9$ & $3,600.2$ \\
\hline \multicolumn{7}{|c|}{$\begin{array}{l}\text { Note individuals of any age who use the internet from any location via any } \\
\text { device at least once per month" "excludes Hong Kong. "'Forecast ffom Aug } \\
2014 \text {; "."includes countries not listed } \\
\text { Source: eMarketer, Nov } 2014\end{array}$} \\
\hline
\end{tabular}

Sumber: emarketer.com

Tabel 1 menunjukkan bahwa penggunaan teknologi internet di Indonesia pada tahun 2016 sebanyak 102,8 juta pengguna. Diperkirakan 2 tahun yang akan datang (tahun 2018) pengguna internet di Indonesia mencapai 123 juta orang atau lebih dari separuh penduduk Indonesia. Apabila dibandingkan dengan data pengguna internet di dunia pada tahun 2016, posisi Indonesia berada diurutan Keenam dibawah China, US, Japan, India, Brazil, dan Japan.

Fenomena perkembangan dan penggunaan Ilmu Pengetahuan serta Teknologi seperti yang telah dipaparkan diatas, sangat mempengaruhi kecenderungan perubahan dalam dunia pendidikan. Hal tersebut diindikasikan dengan: (1) sumber belajar sangat mudah dicari, (2) penggunaan dan pemanfaatan ICT seperti media dan multimedia maupun elearning, mobile learning, web-learning dan lainnya dalam kegiatan pembelajaran, dan (3) model belajar dengan sistim individual learning ataupun blended learning.

Fenomena perkembangan dan penggunaan Ilmu Pengetahuan serta Teknologi seperti yang telah dipaparkan diatas, sangat mempengaruhi kecenderungan perubahan dalam dunia pendidikan. Hal tersebut diindikasikan dengan: (1) sumber belajar sangat mudah dicari, (2) penggunaan dan pemanfaatan ICT seperti media dan multimedia maupun elearning, mobile learning, web-learning dan lainnya dalam kegiatan pembelajaran, dan (3) model belajar dengan sistim individual learning ataupun blended learning.

Persepsi dasar tentang e-learning saat ini secara umum ada dua persepsi, yaitu: (1) Electronic based e-learning adalah pembelajaran yang memanfaatkan teknologi informasi dan komunikasi, terutama perangkat yang berupa elektronik. Pengertian persepsi pertama 
ini, tidak hanya internet, melainkan semua perangkat elektronik seperti film, video, kaset, OHP, Slide, LCD Projector, tape dan lain-lain sejauh menggunakan perangkat elektronik dan (2) Internet based, adalah pembelajaran yang menggunakan fasilitas internet yang bersifat online sebagai instrumen utamanya. Pengertian persepsi kedua ini menekankan bahwa e-learning haruslah menggunakan internet yang bersifat online yaitu komputer yang terhubung dengan internet. Hal ini dapat diartikan bahwa pembelajar dalam mengakses materi pembelajaran tidak terbatas jarak, ruang dan waktu, bisa dimana saja dan kapan saja (any where and any time).

Sistem e-Learning memberikan harapan baru sebagai alternatif solusi atas sebagian besar permasalahan pendidikan di Indonesia, dengan fungsi yang dapat disesuaikan dengan kebutuhan, baik sebagai suplemen (tambahan), komplemen (pelengkap), ataupun substitusi (pengganti) atas kegiatan pembelajaran di dalam kelas yang selama ini digunakan (Wildavsky, 2001; Lewis, 2002). Pemanfaatan sistem e-learning diharapkan akan dapat membantu siswa-siswi dalam meningkatkan belajar baik di ruang kelas maupun di luar kelas. Individu maupun secara berkelompok akan memanfaatkan sistem e-learning apabila sistem tersebut dapat memberikan manfaat bagi dirinya.

Manfaat (perceived usefulness) adalah seberapa jauh seseorang percaya bahwa penggunaan sistem informasi tertentu akan meningkatkan kinerjanya dalam pekerjaan. Manfaat tersebut dapat dikaitkan dengan ekspektasi kinerja (performance expectation). Ekspektasi kinerja adalah tingkat dimana seorang individu meyakini bahwa dengan menggunakan sistem akan dapat membantu dalam meningkatkan kinerjanya. Venkatesh (2000) menggambarkan manfaat sistem bagi pemakainya berkaitan dengan perceived usefullness, motivasi ektrinsik, job performance atau effectiveness (kinerja tugas atau efektifitas), importance to job (pentingnya bagi tugas), dan overall usefullness (kebermanfaatan secara keseluruhan). Dalam organisasi maupun perusahaan ekspektasi kinerja merupakan salah satu faktor yang diharapkan dapat terus terealisir.

Penelitian yang dilakukan oleh Hsu et al. (2011) terhadap pengguna sistem e-learning menggunakan platform moodle dengan membandingkan pembelajaran dengan metode konvensional dan metode sistem e-learning serta untuk mengetahui kesenjangan antara siswa yang berprestasi tinggi dan siswa yang berprestasi rendah. Hasil penelitian menunjukkan bahwa ada hubungan negatif antara efisiensi sistem e-learning dan aksesibilitas ke komputer, sedangkan ada hubungan positif antara frekuensi mengambil sistem e-learning dan nilai ujian siswa.

Model kesuksesan sistem informasi telah banyak dikembangkan oleh para peneliti (Bailey dan Person 1983, DeLone dan McLean 1992, Seddon 1997, Rai et al., 2002). Dari beberapa model kesuksesan sistem informasi tersebut, model DeLone dan McLean (1992) banyak mendapat perhatian dari para peneliti selanjutnya (Mc Gill et al., 2003). Livari (2005) juga menguji secara empiris Model DeLone dan McLean (D dan M) tersebut, hasilnya membuktikan bahwa kesuksesan sistem informasi dipengaruhi oleh kualitas sistem informasi dan kualitas informasi yang dihasilkan dari sistem yang bersangkutan serta kualitas layanan.

Kualitas sistem (system quality) berarti kualitas dari kombinasi hardware dan software dalam sistem informasi. Fokusnya adalah performa dari sistem, dengan merujuk pada seberapa baik kemampuan perangkat keras, perangkat lunak, kebijakan, dan prosedur dari sistem informasi dapat menyediakan informasi sesuai kebutuhan pengguna (DeLone dan McLean, 1992). Bailey dan Pearson (1983) menggunakan empat indikator untuk mengukur kualitas sistem: kemudahan akses, fleksibilitas sistem; integrasi sistem, dan 
waktu respon. Kualitas sistem elektronik dianggap menjadi perhatian utama yang dihadapi oleh para pemangku kepentingan.

Kualitas informasi (information quality) merujuk pada output dari sistem informasi, menyangkut nilai, manfaat, relevansi, dan urgensi dari informasi yang dihasilkan (Pitt et al., 1998). Konstruk ini telah dimasukkan dalam sebagian besar studi dalam hal keberhasilan sistem informasi. Wang dan Strong (1996) mengembangkan kerangka kerja untuk ukuran penting data yang berkualitas bagi konsumen. Dari hasil analisis disimpulkan bahwa ada tiga kategori kualitas data: (1) intrinsik: akurasi, objektivitas, believability, dan reputasi; (2) kontekstual: nilai tambah, relevansi, ketepatan waktu, kelengkapan, dan sesuai jumlah data, dan (3) representasional: interpretability, kemudahan pemahaman, konsistensi representasi, dan representasi singkat.

Kualitas layanan (service quality) merupakan persepsi pengguna atas jasa yang diberikan oleh penyedia sistem e-learning. Pada awalnya ukuran kualitas layanan ini didesain untuk mengukur kepuasan pelanggan oleh Parasuraman et al. (1985). Kualitas layanan merupakan perbandingan antara harapan pelanggan dan persepsi mereka tentang kualitas layanan pelanggan yang diberikan (Parasuraman et al., 1985). Watson et al. (1998) merupakan peneliti pertama yang menerapkan kualitas layanan ini dalam riset sistem informasi.

Penggunaan (use) sistem informasi yang telah dikembangkan mengacu pada seberapa sering pengguna memakai sistem informasi. Semakin sering pengguna memakai sistem informasi, biasanya diikuti oleh semakin banyak tingkat pembelajaran (degree of learning) yang didapat pengguna mengenai sistem informasi Mc Gill et al. (2005). Peningkatan derajat pembelajaran ini merupakan salah satu indikator bahwa terdapat pengaruh antara kualitas sistem terhadap pengguna (individual impact). Namun Livari (2005) memberikan bukti empiris bahwa kualitas sistem dan kualitas informasi tidak berpengaruh signifikan terhadap intensitas penggunaan dan berpengaruh signifikan terhadap kepuasan pengguna. Hal ini dikarenakan obyek penelitian Livari (2005) menggunakan obyek penggunaan sistem yang mandatory.

Proses penyelengaraan sistem e-learning memerlukan sistem yang mampu mengelola pembelajaran secara online, sistem yang biasa dipakai tersebut dikenal dengan LMS (Learning Managemen System). LMS dapat membantu membuat dan menawarkan beberapa course, juga menyediakan kemampuan memperlancar pelajaran dan dapat diintegrasikan dengan LCMS (Learning Content Management System ) dalam membuat kontennya (Horton dan Horton, 2003). Moodle adalah salah satu LMS, yang di perkenalkan pertama kali oleh Martin Dougiamas, seorang computer scientist dan educator di salah satu perguruan tinggi Perth, Australia.

Ketika sebuah institusi telah mengimplementasikan sistem e-learning didalam organisasinya, maka keberhasilan atau efektifitasnya perlu diukur dan ditentukan. Beberapa peneliti diantaranya DeLone dan McLean, (1992); Doll dan Torkzadeh, (1988); Seddon, (1997) berkesimpulan bahwa keberhasilan sistem e-learning sebagian besar dikaitkan dengan user satisfaction serta faktor-faktor lainnya. Stokes (2001) mengemukakan bahwa masalah learner satisfaction dalam lingkungan digital merupakan sesuatu yang sangat penting, sementara model yang dikembangkan oleh DeLone dan McLean (2003) bisa dikatakan sebagai pendekatan yang lebih komprehensif dibandingkan pendekatan model lain yang ada. Model tersebut secara komprehensif mengukur kesuksesan IS sistem e-commerce. Model sukses IS DeLone dan McLean (2003) 
menyebutkan bahwa variabel user satisfaction dipengaruhi oleh beberapa dimensi, diantaranya adalah: information quality, system quality, dan service quality.

Penelitian ini berfokus pada persepsi individu yaitu persepsi individu berkaitan dengan kualitas sistem, kualitas informasi, dan kualitas layanan terhadap penggunaan sistem e-learning. Kesiapan individu terhadap teknologi mengacu pada kecenderungan seseorang untuk menerima dan menggunakan teknologi untuk menyelesaikan tujuan dalam kehidupan sehari-hari dan di tempat kerja (Parasuraman, 2000).

Berdasarkan hal yang telah diuraikan, maka penelitian yang dilakukan bertujuan untuk menganalisis pengaruh kualitas sistem, kualitas informasi, dan kualitas layanan terhadap penggunaan sistem e-learning di Program Pascasarjana Universitas Mercu Buana.

\section{KAJIAN TEORI}

Kualitas Sistem. Kualitas sistem adalah pengukuran proses sistem informasi yang berfokus pada hasil interaksi antara pengguna dan sistem. Kualitas sistem mempunyai atribut-atribut seperti ketersediaan peralatan, reliabilitas peralatan, kemudahan untuk digunakan, dan waktu respon merupakan faktor penentu mengapa sebuah sistem informasi digunakan atau tidak digunakan.

Nielsen (2000) berpendapat bahwa ada beberapa prinsip usability yaitu online environment, namely, navigation, respon time, credibility, dan content. Dari berbagai literatur bahwa ada empat dimensi kualitas sistem yaitu: navigation, easy of use, respon time, dan security. McKinney et al. (2002) mengemukakan bahwa ada tiga dimensi kualitas sistem, ketiga dimensi tersebut adalah: access, usability, dan navigation.

Kualitas sistem dapat diukur dengan melihat bagian fungsionalnya yaitu usability. Usability adalah bagian dari prinsip interaksi antara human computer yang menyediakan satu kumpulan petunjuk penting tentang desain pembelajaran. Nielsen (2000) berpendapat bahwa usability terdiri atas empat prinsip dasar dalam kegiatan online yaitu: navigation, timelines, credibility, dan content. Palmer (2002) berpendapat bahwa beberapa unsur penting dalam penggunaan website adalah konsistensi (concistancy), kemudahaan penggunaan (easy of use), kejelasan dalam berinteraksi (clarity of interaction), kemudahan dalam membaca (easy to reading), pengaturan informasi (information arrangement), kecepatan (speed), dan lay out/rancangan website. Dengan demikian tingkat penggunaan sistem e-learning lebih baik sehingga pelajar dapat lebih termotivasi untuk menggunakan sistem e-learning.

Kualitas sistem memerlukan indikator untuk mengukur seberapa besar kualitas dari sistem informasi. Indikator kualitas sistem diwujudkan dalam seperangkat pertanyaan kualitas sistem yang dapat diukur melalui beberapa indikator sebagai berikut (DeLone dan McLean, 1992): (1) Ease of use (Kemudahan Penggunaan); (2) Response Time (Kecepatan Akses); (3) Reliability (Keandalan Sistem); (4) Flexibility (fleksibilitas); dan (5) Security (keamanan)

Kualitas Informasi. Kualitas informasi berkaitan dengan system use, user satisfaction, dan net benefits (DeLone dan McLean 1992, 2003). Kualitas informasi mempunyai atribut-atribut seperti informasi yang diperoleh dari sebuah sistem, keakuratan informasi, relevansi informasi, ketepatan waktu, dan kelengkapan informasi. Kualitas Informasi sering merupakan dimensi kunci menyangkut instrumen kepuasan pengguna akhir (Ives et al., 1983; Baroudi dan Orlikowski, 1988; Doll et al., 1994). Akibatnya kualitas informasi 
seringkali tidak dibedakan sebagai konstruksi unik tetapi diukur sebagai komponen dari kepuasan pengguna. Oleh karena itu ukuran dimensi ini merupakan masalah bagi studi keberhasilan SI. DeLone dan McLean (1992) dan model Seddon (1997) menunjukkan bahwa kualitas sistem dan kualitas informasi berpengaruh positif signifikan terhadap kepuasan pengguna sistem informasi. Kualitas Informasi yang dimaksudkan dalam penelitian ini merupakan persepsi pemakai mengenai kualitas informasi yang dihasilkan oleh internet yang digunakan oleh mahasiswa guna mendapatkan informasi yang dibutuhkan.

Beberapa karakteristik yang digunakan untuk menilai kualitas informasi antara lain adalah accuracy, timeliness, relevance, informativeness, dan competitiveness (Weber, 1999). Kualitas informasi adalah tingkat relevan (relevant), ketepatan waktu (timely), aman dan disajikan dengan rancangan informasi yang baik dalam sebuah website (Liu dan Arnett, 2000). Kualitas informasi terbaik dapat diberikan oleh internet ketika bisa didapatkan dengan mudah (tidak susah dalam pencariannya), terorganisasi (teratur), dan tersedia dalam jumlah yang banyak (Istianingsih dan Wijanto, 2008). Kualitas informasi juga dapat dilihat dengan adanya potensi menghasilkan informasi yang tidak terbatas baik dalam organisasi maupun luar organisasi (Barnes dan Vidgen, 2003). Menurut Li et al. (2002), informasi yang berkualitas adalah informasi yang akurat, jelas, detil, relevan, mudah didapatkan, tepat waktu, up to date dan sesuai dengan kebutuhan pengguna. Liu dan Arnett (2000) menyatakan bahwa informasi dengan kualitas terbaik akan meningkatkan kegunaan persepsi pengguna dan meningkatkan penggunaan sistem informasi. Lin dan Lu (2000) juga menambahkan bahwa penerimaan atau penolakan pengguna atas sebuah sistem disebabkan oleh kualitas yang diberikan oleh sebuah sistem.

Menurut DeLone dan McLean (1992) kualitas informasi yaitu output yang dihasilkan oleh sistem informasi yang digunakan. Kriteria yang dapat digunakan untuk menilai kualitas informasi antara lain: (1) Kelengkapan (completeness); (2) Relevan (relevance); (3) Akurat (accurate); (4) Ketepatan Waktu (timeliness); dan (5) Penyajian Informasi (format)

Kualitas Layanan. Zeithaml et al. (1990) merumuskan sebuah model yang menggarisbawahi ketentuan penting yang perlu dipatuhi oleh pemberi jasa dalam meningkatkan mutu jasa (service quality). Devaraj et al. (2002) memandang SERQUAL terdiri atas empat dimensi, yaitu: empathy, reliability, responsiveness, dan assurance. Sedang dimensi lainnya adalah price, time, ease of use, dan usefullness.

Kualitas layanan (service quality) yang dikemukakan oleh (Parasuraman, 1988), bahwa didasarkan pada perbandingan antara apa yang seharusnya ditawarkan (offered) dan apa yang disediakan (provided). Perusahaan-perusahaan yang memiliki tingkat kualitas layanan tinggi secara khusus mengembangkan dua sistem informasi yang sangat penting untuk meningkatkan kemampuan service. Pertama sistem informasi yang mengumpulkan informasi kinerja service untuk keperluan manajemen dan motivasi karyawan. Kedua, sistem informasi yang menyebarkan informasi yang dinilai (valued) berguna oleh para pelanggan.

Menurut DeLone dan McLean (2003) kualitas pelayanan menjadi lebih penting dibandingkan penerapan lainnya, karena pemakai-pemakai sistem sekarang adalah lebih sebagai para pelanggan dan bukannya para karyawan atau pemakai internal organisasi. Oleh karena dukungan yang jelek akan menyebabkan kehilangan pelanggan dan bahkan kehilangan penjualan. Kualitas pelayanan dapat dinilai dengan menggunakan kriteria 
sebagai berikut: (1) Kecepatan respon (quick responsiveness); (2) Jaminan (assurance); dan (3) Empati (empathy).

Penggunaan. Davis (1989) meletakkan model dasar penerimaan teknologi berbasis pada penggunaan teknologi dan dampaknya pada individu. Suatu teknologi dikatakan berhasil jika dapat diterima yang diindikasikan dengan keinginan memakai dan bermuara pada pemakaian.

Penggunaan sistem merupakan perilaku yang tepat untuk mengukur kesuksesan suatu sistem informasi yang diterapkan oleh suatu organisasi (Seddon dan Kiew, 1994). Penggunaan sistem informasi ini memperlihatkan keputusan penggunaan sistem informasi oleh pengguna dalam menyelesaikan tugas (Davis, 1989). Dalam model kesuksesan DeLone dan McLean diasumsikan bahwa kualitas sistem informasi dan kualitas informasi yang dihasilkan dapat mempengaruhi penggunaan sistem informasi. Menurut Seddon (1997), penggunaan sistem banyak digunakan untuk mengukur kesuksesan suatu sistem informasi. Variabel penggunaan sistem (use) biasanya digunakan untuk mengukur apakah fungsi suatu sistem informasi secara keseluruhan dapat digunakan untuk tujuan khusus.

Dalam kaji literatur yang dilakukan oleh DeLone dan McLean (1992) ditemukan sekitar 27 penelitian menggunakan pemakaian dan 38 penelitian menggunakan dampak individual sebagai dimensi pengukur kesuksesan sistem informasi. Lebih lanjut, DeLone dan McLean (2003) menegaskan pentingnya dimensi penggunaan dalam mengukur kesuksesan sistem informasi berbasis teknologi. Pada penelitian terdahulu, penggunaan variabel penggunaan sistem dan kepuasan pemakai sebagai indikator kesuksesan suatu sistem telah diteliti oleh Alavi dan Henderson (1981), serta Ginzberg (1981). Disisi lain, variabel penggunaan sistem dan dampak individual yang dihubungkan dengan kesuksesan suatu sistem telah digunakan oleh King dan Rodriguez (1978).

Pada perkembangan lebih lanjut, setelah DeLone dan McLean (1992) mengajukan model kesuksesan sistem informasi mereka, validasi mengenai hubungan positif antara kepuasan pemakai dan penggunaan ditemukan oleh Torkzadeh dan Doll (1999). Hubungan positif antara pemakaian dan dampak individual ditemukan oleh Guimaraes dan Igbaria (1997). Hubungan positif antara penggunaan sistem dan kepuasan pemakai juga ditemukan oleh Wang (2007) serta Wang dan Liao (2007). Validasi hubungan positif antara variabel penggunaan sistem dengan kepuasan pemakai dan variabel pemakaian sistem dengan dampak individual dilakukan oleh Almutairi dan Subramanian (2005) serta Livari (2005).

Penggunaan sistem informasi tersebut dapat dikembangkan mengacu pada seberapa sering pengguna memakai sistem informasi.Semakin sering pengguna memakai sistem informasi biasanya diikuti oleh semakin banyak tingkat pembelajaran (degree of learning) yang didapat pengguna mengenai sistem informasi (Mc Gill et al., 2003). Peningkatan derajat pembelajaran ini merupakan salah satu indikator bahwa terdapat pengaruh keberadaan sistem terhadap kualitas pengguna (individual impact). Individual impact merupakan pengaruh dari keberadaan dan pemakaian sistem informasi terhadap kinerja, pengambilan keoutusan, dan derajat pembelajaran individu dalam organisasi. Leavit dalam Radityo dan Zulaikha (2007) mencermati bahwa penerapan sistem informasi yang baru akan berdampak pada reaksi yang ditunjukkan oleh perilaku individu dalam organisasi. Namun Livari (2005) memberikan bukti empiris bahwa kualitas sistem dan kualitas informasi tidak berpengaruh signifikan terhadap intensitas penggunaannya dan berpengaruh signifikan terhadap kepuasan penggunanya. Hal ini karena obyek penelitian Livari (2005) menggunakan obyek penggunaan sistem yang mandatory. 
Dimensi Keberhasilan penggunaan mewakili derajat dan cara di mana sebuah IS digunakan oleh penggunanya. Mengukur penggunaan IS adalah suatu konsep umum yang dapat dipertimbangkan dari berbagai perspektif. Dalam kasus penggunaan sukarela, penggunaan yang sebenarnya pada IS mungkin merupakan tindakan sukses yang tepat. Sebuah pendekatan yang lebih komprehensif untuk menjelaskan penggunaan IS adalah TAM (Davis 1989). TAM menggunakan variabel independen yang dirasakan kemudahan penggunaan dan kegunaan dirasakan berkontribusi terhadap sikap terhadap penggunaan, niat untuk menggunakan, dan penggunaan aktual. Karena kesulitan dalam menafsirkan dimensi penggunaan, DeLone dan McLean menunjukkan niat untuk menggunakan sebagai langkah alternatif yang akan digunakan untuk beberapa konteks. Penggunaan sistem informasi dapat dinilai dengan menggunakan kriteria: actual use (Davis, 1989); daily use, frequency of use (Almutairi dan Subramanian, 2005; Iivari, 2005); nature of use, navigation patterns, number of site visits, number of transactions (DeLone dan McLean, 2003).

Kerangka Konseptual. Kerangka Konseptual digambarkan secara skematis di bawah ini didasarkan pada teori-teori yang dijelaskan diatas sebagai berikut:

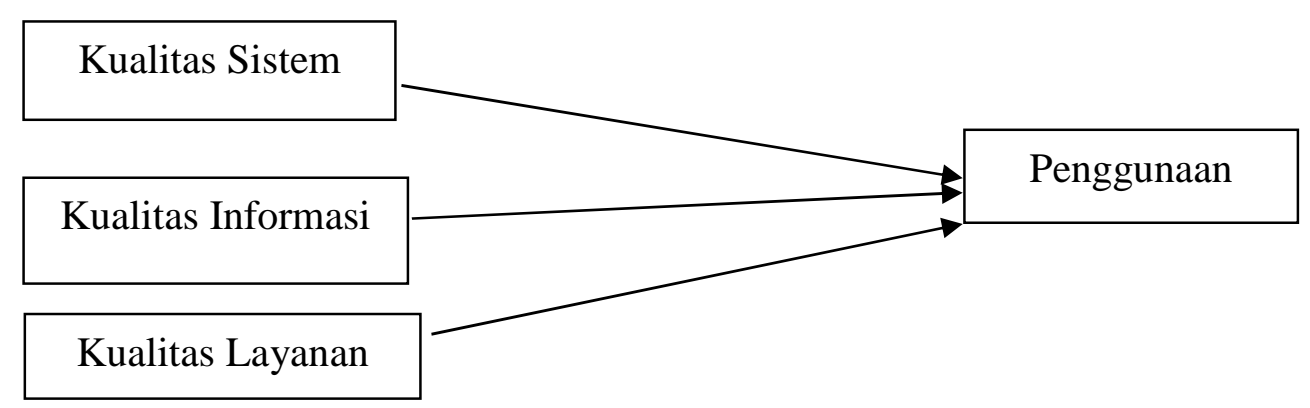

Gambar 1. Skema Kerangka Konseptual

Perumusan Hipotesis. Berdasarkan teori-teori yang telah dikemukakan diatas, maka Hipotesis yang akan diuji dapat dikemukakan sebagai berikut:

$\mathrm{H}_{1}$ : Terdapat pengaruh positif Kualitas Sistem terhadap Penggunaan

$\mathrm{H}_{2}$ : Terdapat pengaruh positif Kualitas Informasi terhadap Penggunaan.

$\mathrm{H}_{3}$ : Terdapat pengaruh positif Kualitas Layanan terhadap Penggunaan.

\section{METODE}

Analisis data yang digunakan pada penelitian ini sesuai dengan bagan alir penelitian, kegiatan awal yang akan dilaksanakan setelah ditemukan permasalahan adalah studi pustaka dan dilanjutkan dengan penyusunan kuesioner. Sesudah kuesinoer disempurnakan dengan menguji valitidas dan reliabilitas, pengumpulan data primer dilaksanakan dengan melakukan survey lapangan. Data hasil survey yang diperoleh kemudian dianalisis menggunakan GSCA (Generalized Structured Component Analysis).

Analisis statistik inferensial dilakukan dengan pendekatan Generalized Structured Component Analysis (GSCA) yang merupakan pendekatan baru terhadap structural equation model - maximum likelihood (SEM-ML) (Hwang dan Takane, 2004, 2007, 2009). GSCA merupakan soft modeling yang powerfull (Ghozali, 2008) karena tidak di 
dasarkan banyak asumsi seperti data tidak harus berdistribusi tertentu (distribution free), sampel tidak harus besar, pada model yang sama dapat digunakan untuk indikator dengan skala nominal, ordinal, interval sampai rasio. Adapun langkah-langkah analisis GSCA adalah sebagai berikut:

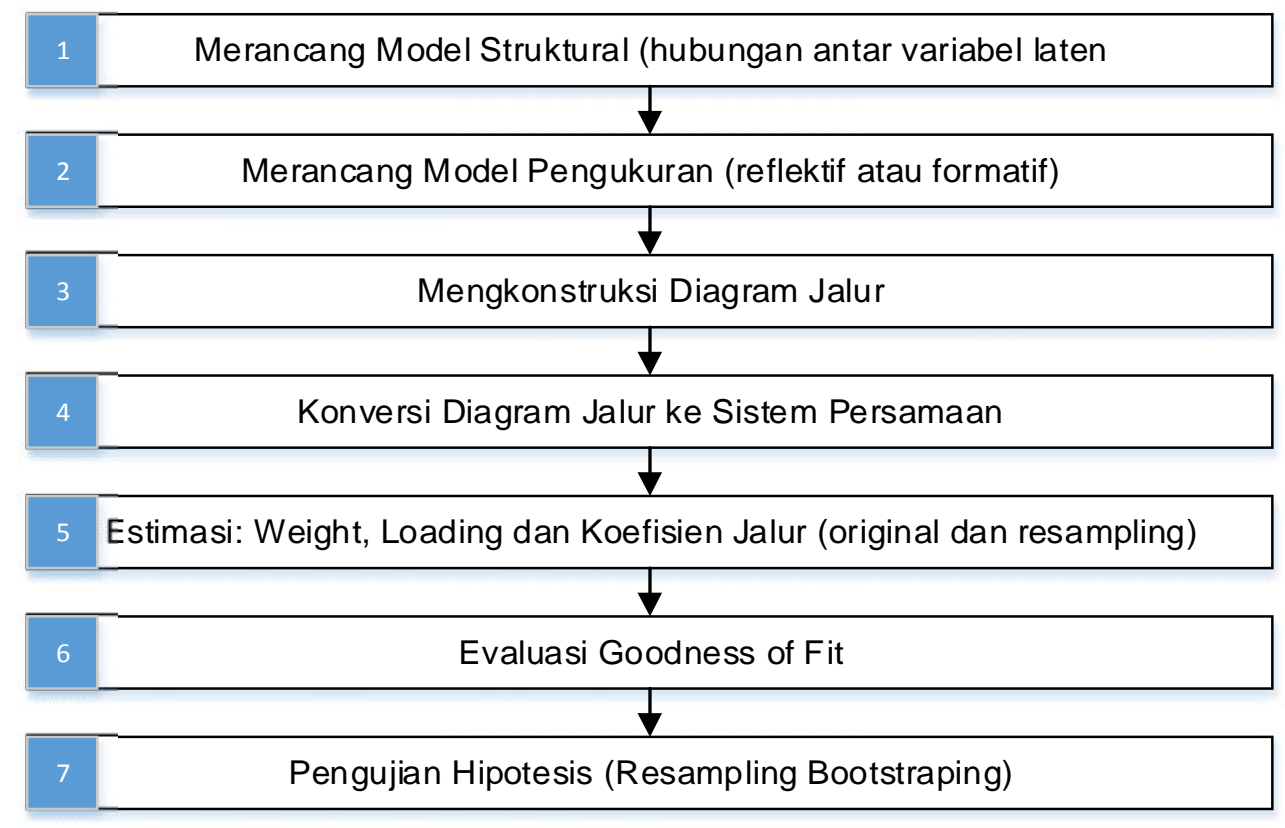

Gambar 1. Langkah-Langkah Analisis GSCA

Analisis Inferensial (Uji Linieritas). Sebelum melakukan analisis pengujian variabel eksogen terhadap variabel endogen dengan menggunakan Generalized Structured Component Analysis (GSCA) terlebih dahulu perlu dilakukan pengujian linieritas. Uji linieritas bertujuan untuk mengetahui apakah dua variabel mempunyai hubungan yang linear atau tidak secara signifikan. Uji ini biasanya digunakan sebagai prasyarat dalam analisis korelasi atau regresi linear. Pengujian pada SPSS dengan menggunakan Test for Linearity dengan pada taraf signifikansi 0.05. Dua variabel dikatakan mempunyai hubungan yang linear bila signifikansi (Linearity) kurang dari 0.05. Pengujian linieritas dimaksudkan untuk mengetahui taraf signifikansi penyimpangan dari linieritas hubungan tersebut. Apabila penyimpangan yang ditemukan tidak signifikan, maka hubungan Antara variabel eksogen dengan variabel endogen adalah linier. Jika hubungan tersebut linier maka pengujian dapat ditindaklanjuti.

Hubungan linieritas ini juga menunjukkan hubungan yang searah. Asumsi linieritas menggunakan metode Curve Fit yaitu hubungan antar variabel dinyatakan linier jika memenuhi salah satu dari kedua kemungkinan berikut: (1) model linier signifikan (sig model linier < 0.05), (2) model linier nonsignifikan dan seluruh model yang mungkin juga nonsignifikan (sig model linier $>0.05$, dan sig model selain linier $>0.05$ ). Spesifikasi model yang digunakan sebagai dasar pengujian adalah model linier, kuadratik, kubik, inverse, logaritmik, power, compound, growth, dan eksponensial. Hasil pengujian linieritas hubungan antar variabel disajikan lengkap disajikan pada Tabel 2. 
Tabel 2. Hasil Uji Linieritas

\begin{tabular}{lccc}
\hline \multicolumn{2}{c}{ Hubungan Antar Variabel } & $\begin{array}{c}\text { Hasil } \\
\text { Pengujian }\end{array}$ & Keterangan \\
\hline Kualitas Sistem (X1) & Penggunaan (Y) & 0.000 & Linier \\
Kualitas Informasi (X2) & Penggunaan (Y) & 0.000 & Linier \\
Kualitas Layanan (X3) & Penggunaan (Y) & 0.000 & Linier \\
\hline
\end{tabular}

Hasil uji linieritas pada Tabel 2 terlihat bahwa seluruh hubungan antar variabel linier dan signifikan dengan tingkat $<0.05$, sehingga dapat dikatakan bahwa asumsi linieritas terpenuhi. Penelitian ini menggunakan variabel reflektif dan normatif. Variabel laten (construct) penelitian ini terdiri atas kualitas sistem, kualitas informasi, kualitas layanan, dan kepuasan penggun. Dengan menggunakan GSCA akan diperoleh identifikasi Godness of Fit

Measurement of Fit Measurement Model Outer model, bilamana indikator reflektif maka diperlakukan evaluasi berupa kalibrasi intrumen yaitu pemeriksaan validitas dan reliabilitas instrument. Oleh karena itu, penerapan GSCA pada data hasil uji coba (try out) pada prinsipnya adalah suatu kegiatan kalibrasi intrumen penelitian, berupa pelaksanaan ujia validitas dan reliabilitas. Uji validitas instrument penelitian pada metode GSCA memuat beberapa hal:

1) Convergent Validity. Validitas ini menggambarkan ukuran korelasi antara skor indicator reflektif dengan skor variabel latennya. Untuk hal ini, loading $0.5-0.6$ dianggap cukup (pada jumlah indicator per variabel laten yang tidak besar, berkisar 3-7 indikator). Pendekatan lain dengan cara melihat hasil pengujian, jika signifikan $(\mathrm{p}<0.05)$ maka dikatakan valid (Solimun, 2012).

2) Diskriminan Validity. Validitas berdasarkan indikator reflektif berdasarkan pada nilai square root of average variance extracted (AVE) dengan membandingkan nilai setiap variabel laten dengan variabel laten lainnya dalam model. Jika korelasi $\mathrm{R}$ square of laten variabel lebih besar dari AVE dengan seluruh variabel laten lainnya maka dikatakan memiliki discriminant validity yang baik. Direkomendasikan nilai pengukuran harus lebih besar dari 0.50 (Solimun, 2012)

3) Internal Consistency Reliability. Kelompok indikator yang mengukur sebuah variabel memiliki reliabilitas internal konsistensi yang baik jika memiliki alpha $\searrow 0.60$ (walaupun bukan merupakan standar yang absolut).

4) Pada indikator formatif ukuran validitas dievaluasi berdasarkan pada substantive content-nya, yaitu dengan melihat signifikansi $(\mathrm{p}<0.05)$ berarti valid (Solimun, 2012).

Analisis GSCA. Pada penelitian ini menggunakan analisis deskriptif dan analisis GSCA. Analisis deskriptif bertujuan untuk mendiskripsikan karakteristik responden yang diteliti serta masing-masing variabel dalam bentuk tabel frekuensi dan angka persentase sehingga informasi yang disampaikan lebih mudah dipahami dan diterima. Analisis statistik inferensial memfokuskan pada bidang kajian analisis dan interpretasi data untuk menarik kesimpulan. Analisis ini digunakan untuk menguji hipotesis penelitian yang telah ditetapkan dengan menggunakan data sampel yang diperoleh. Metode Statistik Inferensial yang digunakan dalam analisis data penelitian ini adalah Generalized Structural Component Analysis (GSCA). Tujuannya adalah menggantikan faktor dengan kombinasi linier dari indik ator (variabel manifest) pada analisis SEM. Pendekatan analisis ini 
menggunakan metode kuadrat terkecil (least square) di dalam proses pendugaan parameter (Solimun, 2012).

GSCA dikembangkan untuk menutupi kekurangan dari PLS (Partial Least Square) yang dilengkapi dengan prosedur optimalisasi global dan juga tetap mempertahankan prosedur optimalisasi local (seperti pada PLS). Metode GSCA juga dapat diterapkan pada hubungan antar variabel yang kompleks (bisa rekursif dan tidak rekursif), melibatkan higher-order komponen (faktor), dan perbandingan multi-group. GSCA adalah metode baru SEM berbasis komponen yang dapat diterapkan pada sampel kecil sampai pada sampel yang sangat besar (Solimun, 2012). GSCA dapat diterapkan pada model structural yang melibatkan variabel dengan indikator reflektif dan formatif, sedangkan pada analisis SEM hanya bisa menganalisis variabel reflektif saja. GSCA dalam prakteknya memperbolehkan terjadinya multikolonieritas, yaitu terjadi korelasi yang kuat antar variabel eksogen (Solimun, 2012).

Model struktural yang dispesifikasi dengan tepat berbasis teori dan hasil-hasil penelitian dengan menggunakan variabel reflektif lebih baik dianalisis menggunakan SEM berbasis kovarians (misal dengan software AMOS atau LISREL). Namun jika model struktural yang menggunakan variabel formatif atau campuran lebih cocok menggunakan analisis GSCA. GSCA bisa digunakan pada dispesifikasi dengan dasar teori dan hasil penelitian belum ada. Analisis SEM berbasis komponen GSCA adalah alternatif yang lebih baik dibandingkan dengan PLS, yaitu memiliki parameter recovery yang lebih baik (Solimun, 2012). Namun demikian GSCA juga dapat diterapkan pada model struktural yang dasar teorinya sudah kuat, atau dengan kata lain sebagai metode analisis konfirmatori.

GSCA dapat menutupi kekurangan SEM berbasis kovarians, yaitu bilamana di dalam model struktural terdapat model indikator formatif. Disamping itu GSCA juga menutupi kekurangan PLS, yaitu bilamana model struktural yang dianalisis bersifat tidak rekursif. Mengingat pada model struktural yang dianalisis pada penelitian ini tidak rekursif dan variabel laten memiliki indikator yang bersifat reflektif dan formatif (campuran), sehingga yang diterapkan dalam penelitian ini adalah analisis GSCA untuk mendapatkan model struktural yang powerfull guna tujuan konfirmasi. Oleh karena itu metode GSCA setara dengan analisis model struktural berbasis kovarians (Solimun, 2012).

Hasil Setiap Pengukuran Konstruk atau Variabel Laten. Model pengukuran diukur berdasarkan nilai loading factor (standardize coefficient) pada setiap item pertanyaan ke indikator dan pada setiap indikator ke variabel laten. Nilai loading factor menunjukkan bobot setiap indikator sebagai pengukur masing-masing variabel. Indikator dengan loading factor besar menunjukkan bahwa indikator tersebut sebagai pengukur variabel terkuat (dominan). Hasil analisis faktor konfirmatori terhadap item-item pertanyaan pada masingmasing variabel disajikan sebagai berikut:

1) Variabel Kualitas Sistem (X1). Analisis variabel kualitas sistem dapat dilihat pada Tabel 3.

Indikator X1.1 yaitu mengenai "kemudahan memahami panduan e-learning" menempati urutan ke-5 dalam mengukur ranking indikator terhadap variabel "kualitas sistem". Rata-rata kemudahan memahami panduan e-learning bernilai 4.28 yang berarti perlu dipertahankan.

Indikator X1.2 yaitu mengenai "kesesuaian materi e-learning dengan kebutuhan belajar" menempati urutan ke-3 dalam mengukur ranking indikator terhadap variabel 
"kualitas sistem". Rata-rata kesesuaian materi e-learning dengan kebutuhan belajar bernilai 3.48 yang berarti perlu dipertahankan atau bahkan ditingkatkan.

Tabel 3. Analisis Variabel Kualitas Sistem

\begin{tabular}{ccccc}
\hline \multirow{2}{*}{ Indikator } & \multicolumn{3}{c}{ Weight } & \multirow{2}{*}{ Rata-Rata } \\
\cline { 2 - 3 } & Estimate & SE & CR & \\
\hline X1.1 & 0.490 & 0.078 & $6.26^{*}$ & 4.28 \\
X1.2 & 0.619 & 0.084 & $7.36^{*}$ & 3.48 \\
X1.3 & 0.688 & 0.051 & $13.57^{*}$ & 3.81 \\
X1.4 & 0.570 & 0.095 & $5.98^{*}$ & 3.97 \\
X1.5 & 0.900 & 0.019 & $48.01^{*}$ & 3.48 \\
X1.6 & 0.461 & 0.108 & $4.25^{*}$ & 3.48 \\
\hline
\end{tabular}

Indikator X1.3 yaitu mengenai "kemanfaatan e-learning untuk menunjang proses pembelajaran" menempati urutan ke-2 dalam mengukur ranking indikator terhadap variabel "kualitas sistem". Rata-rata kemanfaatan e-learning untuk menunjang proses pembelajaran bernilai 3.81 yang berarti perlu dipertahankan atau bahkan ditingkatkan.

Indikator X1.4 yaitu mengenai "kemudahan pengoperasian e-learning" menempati urutan ke-4 dalam mengukur ranking indikator terhadap variabel "kualitas sistem". Ratarata kemudahan pengoperasian e-learning bernilai 3.97 yang berarti perlu dipertahankan atau bahkan ditingkatkan.

Indikator X1.5 yaitu mengenai "keintensifan komunikasi antara pengajar dan mahasiswa karena sistem e-learning" menempati urutan ke-1 dalam mengukur ranking indikator terhadap variabel "kualitas sistem". Rata-rata keintensifan komunikasi antara pengajar dan mahasiswa karena sistem e-learning bernilai 3.48 yang berarti perlu dipertahankan atau bahkan ditingkatkan.

Indikator X1.6 yaitu mengenai "kemudahan dalam mengakses fitur e-learning" menempati urutan ke-6 dalam mengukur ranking indikator terhadap variabel "kualitas sistem". Rata-rata kemudahan dalam mengakses fitur e-learning bernilai 3.48 yang berarti perlu dipertahankan atau bahkan ditingkatkan.

Data pada Tabel 3 diperoleh informasi bahwa keintensifan komunikasi antara pengajar dan mahasiswa menggunakan sistem e-learning (X1.5) memiliki nilai estimate 0.900 (terbesar) namun memiliki rata-rata indikator yang rendah. Indikator X1.5 merupakan indikator yang paling kuat sebagai pengukur variabel kualitas sistem namun masih perlu perbaikan (3.48). Indikator X1.1 mengenai kemudahan memahami panduan elearning memiliki nilai estimate 0.490 (menempati urutan ke-5) namun memiliki nilai ratarata indikator yang sudah cukup baik (4.28) dan masih perlu dilakukan perbaikan. Dengan melihat informasi tersebut, pengelola e-learning di UMB diharapkan untuk meningkatkan kualitas sistem agar pengguna sistem e-learning lebih termotivasi untuk menggunakan sistem e-learning. Langkah yang diperlukan dalam peningkatan kualitas sistem diantaranya: (1) sistem informasi yang lebih fleksibel, mudah dipahami dan mudah pengoperasiannya, (2) sistem yang mempunyai kecepatan akses, (3) sistem yang mempunyai keandalan, dan (4) sistem yang lebih mempunyai keamanan yang dapat diandalkan. 
2) Variabel Kualitas Informasi (X2). Analisis variabel kualitas informasi dapat dilihat pada Tabel 4.

Tabel 4. Analisis Variabel Kualitas Informasi

\begin{tabular}{ccccc}
\hline \multirow{2}{*}{ Indikator } & \multicolumn{3}{c}{ Weight } & \multirow{2}{*}{ Rata-Rata } \\
\cline { 2 - 4 } & Estimate & SE & CR & \\
\hline X2.1 & 0.595 & 0.059 & $10.01^{*}$ & 4.21 \\
X2.2 & 0.645 & 0.056 & $11.57^{*}$ & 4.02 \\
X2.3 & 0.702 & 0.045 & $15.72^{*}$ & 3.34 \\
X2.4 & 0.639 & 0.058 & $11.07^{*}$ & 3.33 \\
X2.5 & 0.837 & 0.020 & $42.47^{*}$ & 3.74 \\
\hline
\end{tabular}

Indikator X2.1 yaitu mengenai "kejelasan informasi tentang meteri perkuliahan pada sistem e-learning" menempati urutan ke-5 dalam mengukur ranking indikator terhadap variabel "kualitas informasi". Rata-rata kejelasan informasi tentang meteri perkuliahan pada sistem e-learning bernilai 4.21 yang berarti perlu dipertahankan.

Indikator X2.2 yaitu mengenai "kerincian informasi mengenai materi perkuliahan pada e-learning" menempati urutan ke-3 dalam mengukur ranking indikator terhadap variabel "kualitas informasi". Rata-rata kerincian informasi mengenai materi perkuliahan pada e-learning bernilai 4.02 yang berarti perlu dipertahankan atau bahkan ditingkatkan.

Indikator X2.3 yaitu mengenai "ketepatan waktu dalam penyajian informasi" menempati urutan ke-2 dalam mengukur ranking indikator terhadap variabel "kualitas informasi". Rata-rata ketepatan waktu dalam penyajian informasi bernilai 3.34 yang berarti perlu sedikit diperbaiki.

Indikator X2.4 yaitu mengenai "ketertarikan terhadap design e-learning" menempati urutan ke-4 dalam mengukur ranking indikator terhadap variabel "kualitas informasi". Rata-rata ketertarikan terhadap design e-learning bernilai 3.33 yang berarti perlu sedikit diperbaiki.

Indikator X2.5 yaitu mengenai "keakuratan penilaian kuis di e-learning" menempati urutan ke-1 dalam mengukur ranking indikator terhadap variabel "kualitas informasi". Rata-rata keakuratan penilaian kuis di e-learning bernilai 3.74 yang berarti perlu dipertahankan atau bahkan ditingkatkan.

Merujuk pada Tabel 4 diperoleh informasi bahwa keakuratan penilaian kuis dalam sistem e-learning (X2.5) mempunyai nilai estimate sebesar 0.837, sehingga merupakan indikator yang paling kuat dalam mengukur variabel kualitas informasi (X2), namun nilai estimate yang tinggi tersebut memiliki rata-rata indikator yang masih rendah (3.74), sehingga masih perlu dilakukan perbaikan. Sedangkan indikator X2.1 mengenai kejelasan informasi tentang materi perkuliahan pada sistem e-learning memiliki nilai estimate terendah sebesar 0.595 namun memiliki nilai rata-rata indikator yang paling tinggi (4.21) sehingga masih perlu dilakukan perbaikan. Penyelenggara sistem e-learning di program pascasarjana UMB diharapkan untuk lebih meningkatkan kualitas informasi untuk membangun kepercayaan dalam hubungan antara pengguna dan sistem, sehingga mempengaruhi kepuasan pengguna dan penggunaan. Peningkatan kepercayaan pemakai sistem informasi, diharapkan akan semakin meningkatkan kinerja. Langkah yang diperlukan dalam peningkatan kualitas informasi diantaranya: (1) kualitas informasi yang 
mempunyai kelengkapan (completeness), (2) kualitas informasi tersebut harus relevan terhadap kebutuhan pengguna, (3) kualitas informasi yang mempunyai keakuratan sehingga sumber informasi sampai ke penerima, (4) kualitas informasi yang dihasilkan tepat waktu, dan (5) kualitas informasi mempunyai format untuk memudahkan pengguna dalam memahami informasi yang disediakan. Jika informasi yang dihasilkan dari sistem yang digunakan semakin akurat, tepat waktu, dan memiliki reliabilitas yang baik, maka akan semakin meningkatkan kepercayaan pemakai sistem tersebut. Peningkatan kepercayaan pemakai sistem informasi, diharapkan akan semakin meningkatkan kinerja.

3) Variabel Kualitas Layanan (X3). Analisis variabel kualitas layanan dapat dilihat pada Tabel 5.

Tabel 5. Analisis Variabel Kualitas Layanan

\begin{tabular}{ccccc}
\hline \multirow{2}{*}{ Indikator } & \multicolumn{3}{c}{ Weight } & \multirow{2}{*}{ Rata-Rata } \\
\cline { 2 - 4 } & Estimate & SE & CR & \\
\hline X3.1 & 0.503 & 0.067 & $7.47^{*}$ & 4.47 \\
X3.2 & 0.368 & 0.069 & $5.31^{*}$ & 4.21 \\
X3.3 & 0.336 & 0.058 & $5.81^{*}$ & 3.98 \\
\hline
\end{tabular}

Indikator X3.1 yaitu mengenai "kecepatan download materi perkuliahan" menempati urutan ke-1 dalam mengukur ranking indikator terhadap variabel "kualitas layanan". Ratarata kecepatan download materi perkuliahan bernilai 4.47 yang berarti perlu dipertahankan.

Indikator X3.2 yaitu mengenai "penilaian hasil pembelajaran sistem e-learning" menempati urutan ke-2 dalam mengukur ranking indikator terhadap variabel "kualitas layanan". Rata-rata penilaian hasil pembelajaran sistem e-learning bernilai 4.21 yang berarti perlu dipertahankan.

Indikator X3.3 yaitu mengenai "kemudahan dalam menghubungi petugas e-learning" menempati urutan ke-3 dalam mengukur ranking indikator terhadap variabel "kualitas layanan". Rata-rata kemudahan dalam menghubungi petugas e-learning bernilai 3.98 yang berarti perlu dipertahankan atau bahkan ditingkatkan.

Merujuk pada Tabel 5 diperoleh informasi mengenai kemudahan dalam menghubungi petugas e-learning (X3.3) mempunyai nilai estimate sebesar 0.336, sehingga merupakan indikator yang paling lemah dalam mengukur variabel kualitas layanan (X3), serta memiliki rata-rata indikator yang masih rendah juga (3.98), sehingga masih perlu dilakukan perbaikan. Penyelenggara sistem e-learning di program pascasarjana UMB diharapkan untuk lebih meningkatkan kualitas layanan untuk menentukan komponen layanan yang diharapkan diperoleh oleh pengguna sistem e-learning sehingga mereka tidak enggan untuk menggunakannya. Langkah yang diperlukan dalam peningkatan kualitas sistem diantaranya: (1) kecepatan respon (quick responsiveness) berupa kecepatan dan ketanggapan sistem e-learning dalam merespon akses sistem, (2) jaminan (assurance) berkaitan dengan pengetahuan, kesopanan, dan kemampuan dari pengelola sistem elearning untuk membangkitkan rasa kepercayaan dan keyakinan dari pengguna sistem elearning, (3) empati (empathy) berupa perhatian dan kepedulian pengelola sistem elearning ke pengguna. 
4) Variabel Penggunaan (Y). Analisis variabel penggunaan dapat dilihat pada Tabel 6.

Tabel 6. Analisis Variabel Penggunaan

\begin{tabular}{ccccc}
\hline \multirow{2}{*}{ Indikator } & \multicolumn{3}{c}{ Weight } & \multirow{2}{*}{ Rata-Rata } \\
\cline { 2 - 4 } & Estimate & SE & CR & \\
\hline Y1.1 & 0.798 & 0.030 & $26.97^{*}$ & 3.44 \\
Y1.2 & 0.756 & 0.033 & $23.0^{*}$ & 2.79 \\
Y1.3 & 0.692 & 0.040 & $17.4^{*}$ & 3.21 \\
Y1.4 & 0.325 & 0.075 & $4.32^{*}$ & 3.07 \\
\hline \hline
\end{tabular}

Indikator Y1.1 yaitu mengenai "selalu menggunakan sistem e-learning untuk perkuliahan" menempati urutan ke-1 dalam mengukur ranking indikator terhadap variabel "penggunaan". Rata-rata frekuensi penggunaan e-learning untuk perkuliahan bernilai 3.44 yang berarti perlu dipertahankan atau bahkan ditingkatkan.

Indikator Y1.2 yaitu mengenai "menggunakan sistem e-learning karena ada panduan yang jelas" menempati urutan ke-2 dalam mengukur ranking indikator terhadap variabel "penggunaan". Rata-rata lama waktu mengakses e-learning bernilai 2.79 yang berarti perlu sedikit diperbaiki.

Indikator Y1.3 yaitu mengenai "frekwensi kunjungan ke sistem e-learning" menempati urutan ke-3 dalam mengukur ranking indikator terhadap variabel "penggunaan". Rata-rata frekuensi kunjungan ke sistem e-learning bernilai 3.21 yang berarti perlu sedikit diperbaiki.

Indikator Y1.4 yaitu mengenai "selalu mengikuti kuis dengan sistem e-learning" menempati urutan ke-4 dalam mengukur ranking indikator terhadap variabel "penggunaan". Rata-rata motivasi menggunakan e-learning kembali bernilai 3.07 yang berarti perlu sedikit diperbaiki.

Merujuk pada Tabel 6 diperoleh informasi mengenai selalu menggunakan sistem elearning untuk perkuliahan (Y1.1), mempunyai nilai estimate sebesar 0.798, menggunakan sistem e-learning karena ada panduan yang jelas (Y1.2) mempunyai nilai estimate sebesar 0.756, dan frekwensi kunjungan ke sistem e-learning (Y1.3) mempunyai nilai estimate sebesar 0.692 dan rata-rata indikator Y1.1 sebesar 3.44, rata-rata indikator Y1.2 sebesar 2.79, rata-rata indikator Y1.3 sebesar 3.21 sehingga ketiga indikator tersebut perlu mendapatkan perbaikan. Setelah ketiganya mendapatkan perbaikan barulah memperbaiki selalu mengikuti kuis dengan sistem e-learning (Y1.4) dengan nilai estimate sebesar 0.325 (terendah) yang nilainya hampir separuh dari ketiganya. Penyelenggara sistem e-learning di Program Pascasarjana Universitas Mercu Buana diharapkan untuk lebih meningkatkan penggunaan untuk mengukur apakah fungsi suatu sistem informasi secara keseluruhan dapat digunakan untuk tujuan pembelajaran online. Langkah yang diperlukan dalam peningkatan penggunaan diantaranya: (1) lebih meningkatkan desain sistem e-learning yang menarik dan user friendly, (2) lebih meningkatkan fitur-fitur yang menarik, (3) menyediakan fasilitas Wifi di lingkungan kampus sehingga mahasiswa bisa mengakses elearning dengan mudah, dan (4) materi perkuliahan yang lengkap sesuai dengan mata kuliah yang diajarkan.

Hubungan Kualitas Sistem, Kualitas Informasi, Kualitas Layanan, dan Penggunaan. Dalam model struktural ini, diuji tiga hubungan antar variabel dikelompokkan menjadi 
variabel eksogen dan variabel endogen. Variabel eksogen dalam penelitian ini adalah kualitas sistem (X1), kualitas informasi (X2), kualitas layanan (X3), sedangkan variabel endogen terdiri atas variabel penggunaan (Y). Model dikatakan baik jika pengembangan model hipotetik secara teoritis didukung oleh data empirik. Hasil uji model disajikan pada Tabel 7 dan dilakukan evaluasi berdasarkan Goodness of Fit (GFI) sebagai berikut:

Tabel 7. Measurement Model Pengukuran

\begin{tabular}{cc}
\hline \multicolumn{3}{c}{ Model Fit } \\
\hline FIT & 0.589 \\
AFIT & 0.566 \\
NPAR & 69 \\
\hline
\end{tabular}

FIT $=$ 0.589. FIT menunjukkan varian total dari semua variabel yang dapat dijelaskan oleh model tertentu. Nilai FIT yang bagus adalah berkisar antara 0 hingga 1, dimana apabila nilai FIT semakin besar maka variance dari data tersebut dapat dijelaskan dalam model (Ghozali, 2008). Dari Tabel 7 diatas terlihat bahwa model yang terbentuk dapat menjelaskan semua variabel yang ada sebesar 0.589. Keragaman yang dapat dijelaskan oleh model adalah sebesar 58.9\%, dengan demikian model bisa dikatakan cukup baik.

AFIT = 0.566. AFIT (Adjusted Fit) mirip dengan analisis R square adjusted disesuaikan. AFIT dapat digunakan untuk perbandingan model. Model dengan AFIT nilai terbesar dapat dipilih antara model yang lebih baik. Jika dilihat AFIT pada Tabel 7 sebesar 0.566 artinya keragaman yang dapat dijelaskan oleh model sebesar 56.6\%.

Pengujian Hipotesis. Berdasarkan data empirik yang diajukan dalam penelitian ini dapat dilakukan pengujian terhadap hipotesis yang diajukan. Tabel 8 merupakan pengujian hipotesis dengan melihat nilai estimate dan SE (Standard Error), jika nilainya lebih kecil dari 0.05 maka hubungan antar variabel signifikan.

Tabel 8. Rekapitulasi Hasil Uji Hipotesis

\begin{tabular}{clccccc}
\hline $\begin{array}{c}\text { Hipo- } \\
\text { tesis }\end{array}$ & $\begin{array}{c}\text { Hubungan Antar } \\
\text { Variabel }\end{array}$ & Estimate & SE & CR & P-Value & Keterangan \\
\hline H1 & $\begin{array}{l}\text { kualitas sistem }> \\
\text { penggunaan }\end{array}$ & 0.254 & 0.06 & $4.25^{*}$ & 0.000 & Signifikan \\
H2 & $\begin{array}{l}\text { kualitas informasi }> \\
\text { penggunaan }\end{array}$ & 0.286 & 0.041 & $6.98^{*}$ & 0.000 & Signifikan \\
H3 & $\begin{array}{l}\text { kualitas layanan }> \\
\text { penggunaan }\end{array}$ & 0.207 & 0.034 & $6.17^{*}$ & 0.000 & Signifikan \\
\hline
\end{tabular}

$\mathrm{CR}^{*}=$ significant at .05 level

Adapun interpretasi dari Tabel 8 dapat dijelaskan sebagai berikut:

1) Hasil koefisien pengaruh kualitas sistem terhadap penggunaan sebesar 0.254 , dengan standard error sebesar 0.06 dengan nilai critical ratio dan p-value berurutan adalah sebesar 4.25 dan 0 . Karena p-value $(0)<0.05$ maka dapat disimpulkan pengaruh kualitas sistem terhadap penggunaan signifikan. Artinya semakin tinggi kualitas sistem maka semakin tinggi pula penggunaan.

2) Hasil koefisien pengaruh kualitas informasi terhadap penggunaan sebesar 0.286 , dengan standard error sebesar 0.041 dengan nilai critical ratio dan p-value berurutan adalah sebesar 6.98 dan 0 . Karena p-value $(0)<0.05$ maka dapat disimpulkan 
pengaruh kualitas informasi terhadap penggunaan signifikan. Artinya semakin tinggi kualitas informasi maka semakin tinggi pula penggunaan.

3) Hasil koefisien pengaruh kualitas layanan terhadap penggunaan sebesar 0.207 , dengan standard error sebesar 0.034 dengan nilai critical ratio dan p-value berurutan adalah sebesar 6.17 dan 0 . Karena p-value $(0)<0.05$ maka dapat disimpulkan pengaruh kualitas layanan terhadap penggunaan signifikan. Artinya semakin tinggi kualitas layanan maka semakin tinggi pula penggunaan.

Pengaruh Kualitas Sistem (X1) Terhadap Penggunaan (Y). Pengujian hipotesis antara hubungan kualitas sistem terhadap penggunaan secara lengkap disajikan pada Tabel 8, secara grafik disajikan sebagai berikut:

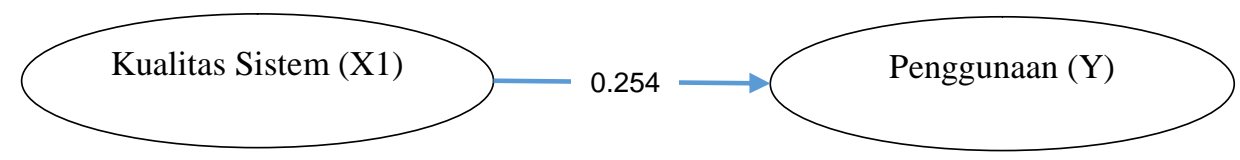

Analisis GSCA menghasilkan nilai estimate sebesar 0.254 dan nilai critical ratio sebesar $4.25^{*}$ sehingga kualitas sistem berpengaruh signifikan terhadap penggunaan. Mengingat nilai estimate tersebut bertanda positif, ini berarti bahwa terdapat hubungan yang searah antara kualitas sistem dengan kualitas informasi, yaitu semakin tinggi kualitas sistem e-learning yang disediakan oleh Program Pascasarjana Universitas Mercu Buana maka semakin tinggi pula tingkat penggunaan sistem e-learning di Program Pascasarjana Universitas Mercu Buana.

Temuan penelitian ini mengkonfirmasi dan memperluas teori dari Davis et al. (1989) dan juga Chin dan Todd (1995) menegaskan bahwa kualitas sistem sebagai perceived ease of use, dengan pengertian seberapa besar teknologi komputer dirasakan relatif mudah untuk dipahami dan digunakan. Perceived usefulness didefinisikan sebagai tingkat dimana seseorang percaya bahwa dengan menggunakan sistem tertentu dapat meningkatkan kinerja (Davis, 1989).

Temuan penelitian ini mengkonfirmasi dan memperluas teori dari (DeLone dan McLean, 1992) yang menyatakan bahwa kualitas sistem (system quality) berarti kualitas dari kombinasi hardware dan software dalam sistem informasi. Fokusnya adalah performa dari sistem, yang merujuk pada seberapa baik kemampuan perangkat keras, perangkat lunak, kebijakan, dan prosedur dari sistem informasi dapat menyediakan informasi kebutuhan pengguna. Bailey dan Pearson (1983) menggunakan empat indikator untuk mengukur kualitas sistem: kemudahan akses, fleksibilitas sistem; integrasi sistem, dan waktu respon. Banyak penelitian telah dilakukan untuk menyelidiki kualitas sistem elearning dan berusaha untuk mengidentifikasi indikator yang dapat mengukur konstruksi ini secara efektif. Volery dan Lord (2000) menyelidiki faktor penentu keberhasilan dalam pendidikan online. Studi empiris mereka menyimpulkan bahwa kualitas sistem merupakan faktor kunci dalam mengukur pendidikan online. Kualitas sistem dalam pendidikan online diukur menggunakan dua indikator: kemudahan akses dan navigasi antarmuka. Holsapple dan Lee-Post (2006) mengukur kualitas sistem e-learning dengan enam Indikator: kemudahan penggunaan, keramahan pengguna, stabilitas, keamanan, kecepatan, dan responsif.

Temuan penelitian ini juga mengkonfirmasi dan memperluas penelitian yang dilakukan oleh: Sedon dan Kiew (1996), Shaberwal et al., (2006), Halawi et al. (2007), Hsieh dan Wang (2007), Petter dan McLean (2009), Freeze et al., (2010). Petter dan McLean (2009) melakukan penelitian meta-analisis menggunakan DeLone dan Mclean 
(2003) model, untuk menentukan apakah model telah divalidasi oleh studi penelitian terdahulu. Hasil penelitian Petter dan McLean (2009) adalah: terjadi hubungan yang kuat antara variabel: user satisfaction dan intention to use, net benefits dan intention to use, system quality dan user satisfaction, user satisfaction dan net benefits, information quality dan user satisfaction, information quality dan intention to use, serta system quality dan intention to use; serta terjadi hubungan yang moderate antara information quality dan use, use dan individual impact, serta system quality dan use.

Temuan penelitian ini juga mengkonfirmasi dan memperluas penelitian oleh Freeze, et al. (2010) melakukan penelitian menggunakan model ISS untuk mempelajari sistem elearning (ELS) dalam konteks dampak individual untuk siswa dalam pembelajaran secara online. Penelitian ini dibangun di atas premis bahwa kualitas sistem (SQ) dan kualitas informasi (IQ) berpengaruh terhadap penggunaan sistem dan kepuasan pengguna, yang pada gilirannya berdampak pada keberhasilan sistem. Semua hipotesis yang disajikan dalam model penelitian, H1 sampai dengan H6, mencapai tingkat signifikansi 0,01. Jalur koefisien H2 (kepuasan pengguna keberhasilan sistem) memiliki efek paling kuat pada keberhasilan sistem. Faktor yang paling signifikan dengan t hitung sebesar 31.25 dan standar koefisien sebesar 0.94. Kualitas sistem dan kualitas informasi memiliki pengaruh positif signifikan terhadap kepuasan pengguna dan penggunaan sistem. Sementara kualitas sistem memiliki pengaruh sedikit lebih kuat pada kepuasan pengguna (dengan koefisien jalur 0,48) dibandingkan dengan Kualitas informasi (dengan koefisien jalur 0,45). Sehubungan dengan penggunaan sistem, kualitas informasi (0.31) memiliki pengaruh yang sedikit lebih kuat pada penggunaan sistem dari pada kualitas sistem (0.29).

Pengaruh Kualitas Informasi (X2) Terhadap Penggunaan (Y). Pengujian hipotesis antara hubungan kualitas informasi terhadap kepuasan pengguna secara lengkap disajikan pada Tabel 8, secara grafik disajikan sebagai berikut:

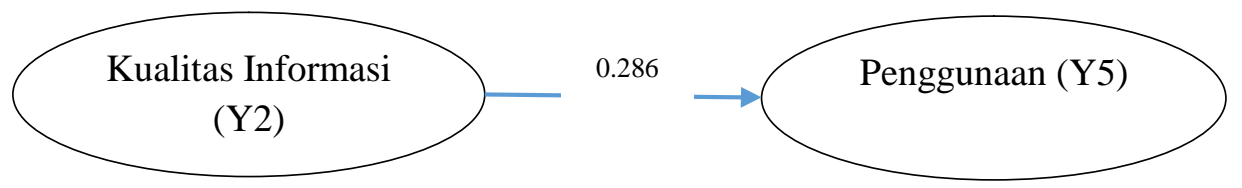

Analisis GSCA menghasilkan nilai estimate sebesar 0.286 dan nilai critical ratio sebesar $6.98^{*}$ sehingga kualitas informasi berpengaruh signifikan terhadap penggunaan. Mengingat nilai estimate tersebut bertanda positif, ini berarti bahwa terdapat hubungan yang searah antara kualitas informasi dengan penggunaan, yaitu semakin tinggi kualitas informasi yang disediakan sistem e-learning semakin baik maka akan menyebabkan semakin tinggi pula tingkat penggunaan sistem e-learning.

Temuan penelitian ini mengkonfirmasi dan memperluas hasil penelitian yang dilakukan oleh Delone dan Mclean (2003), Hisham (2003), Isitaningsih dan Wijayanto (2008), dan Lederer et al. (2000). Hisham (2003) dalam penelitiannya mengenai analisis pengaruh kualitas informasi, kualitas sistem, dan kualitas layanan terhadap niat penggunaan e-learning, menyatakan bahwa kualitas informasi merupakan faktor yang paling berpengaruh signifikan dalam meningkatkan niat penggunaan teknologi informasi bagi pelajar dalam lingkungan on-line. Temuan penelitian ini juga mengkonfirmasi dan memperluas hasil penelitian yang dilakukan Lederer et al. (2000) yang menunjukkan bahwa kualitas informasi merupakan variabel yang paling berpengaruh positif signifikan terhadap minat pemanfaatan sistem teknologi dalam penelitiannya mengenai the technology acceptance model and the world wide web. 
Temuan penelitian ini juga mengkonfirmasi dan memperluas hasil penelitian yang dilakukan oleh (Seddon, 1997) untuk melihat adanya hubungan antara kualitas informasi dengan perceived usefulness. Hasil penelitian menunjukkan adanya hubungan antara dua variabel ini, didukung oleh hasil penelitian Li (1997) dan Rai et al. (2002). Jika pengguna internet yakin dengan kualitas sistem yang digunakannya dan merasakan bahwa menggunakan sistem tersebut tidak sulit, maka mereka akan percaya bahwa penggunaan sistem tersebut akan memberikan manfaat yang lebih besar dan akan meningkatkan kinerja mereka. Jika informasi yang dihasilkan dari sistem yang digunakan semakin akurat, tepat waktu, dan memiliki reliabilitas yang baik, maka akan semakin meningkatkan kepercayaan pemakai sistem tersebut. Peningkatan kepercayaan pemakai sistem informasi, diharapkan akan semakin meningkatkan kinerja.

Temuan penelitian ini juga mengkonfirmasi dan memperluas hasil penelitian yang dilakukan oleh: Godhue dan Thompson (1995), Rai et al. (2002), Halawi et al., (2007), Petter dan McLean (2009), Freeze et al. (2010), serta Saba (2012). Freeze et al. (2010) melakukan penelitian menggunakan model ISS untuk mempelajari sistem e-learning (ELS) dalam konteks dampak individual untuk siswa dalam pembelajaran secara online. Penelitian ini dibangun di atas premis bahwa kualitas sistem (SQ) dan kualitas informasi (IQ) berpengaruh terhadap penggunaan sistem dan kepuasan pengguna, yang pada gilirannya berdampak pada keberhasilan sistem. Semua hipotesis yang disajikan dalam model penelitian, H1 sampai dengan H6, mencapai tingkat signifikansi 0,01. Jalur koefisien H2 (kepuasan pengguna $\square$ keberhasilan sistem) memiliki efek paling kuat pada keberhasilan sistem. Faktor yang paling signifikan dengan t hitung sebesar 31.25 dan standar koefisien sebesar 0.94. Kualitas sistem dan kualitas informasi memiliki pengaruh positif signifikan terhadap kepuasan pengguna dan penggunaan sistem. Sementara kualitas sistem memiliki pengaruh sedikit lebih kuat pada kepuasan pengguna (dengan koefisien jalur 0,48) dibandingkan dengan Kualitas informasi (dengan koefisien jalur 0,45). Sehubungan dengan penggunaan sistem, kualitas informasi (0.31) memiliki pengaruh yang sedikit lebih kuat pada penggunaan sistem dari pada kualitas sistem (0.29).

Temuan penelitian ini tidak mengkonfirmasi penelitian yang dilakukan oleh: McGill et al. (2003) dan Iivari (2005). Hasil penelitian yang dilakukan oleh McGill et al, (2003): dari sembilan hubungan hipotesis diuji, empat hipotesis ditemukan signifikan dan sisanya tidak signifikan. Hubungan hipotesis ditemukan signifikan tersebut adalah: kualitas sistem yang dirasakan $\rightarrow$ kepuasan pengguna (H3); kualitas informasi $\rightarrow$ kepuasan pengguna (H2), kepuasan pengguna $\rightarrow$ penggunaan (H6), dan kepuasan pengguna dan dampak individual (H8). Hubungan hipotesis ditemukan tidak signifikan tersebut adalah: kualitas sistem $\rightarrow$ kualitas sistem $(\mathrm{H} 1)$; kualitas informasi $\rightarrow$ penggunaan $(\mathrm{H} 4)$; kualitas sistem $\rightarrow$ penggunaan (H5), penggunaan $\rightarrow$ dampak individual (H7), dan dampak individual $\rightarrow$ dampak organisasi (H9).

Pengaruh Kualitas Layanan (X3) Terhadap Penggunaan (Y). Pengujian hipotesis antara hubungan kualitas layanan terhadap kepuasan pengguna secara lengkap disajikan pada Tabel 8, secara grafik disajikan sebagai berikut:

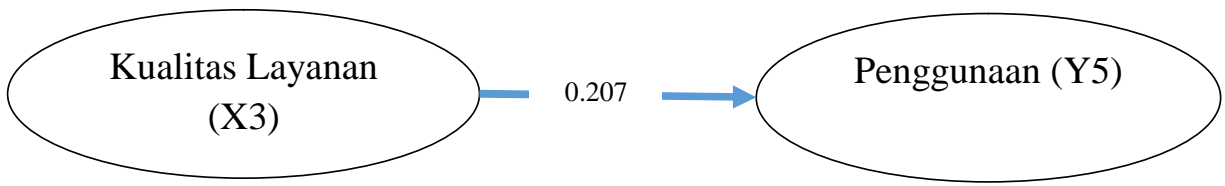

Analisis GSCA menghasilkan nilai estimate sebesar 0.207 dan nilai critical ratio sebesar $6.17 *$ sehingga kualitas layanan berpengaruh signifikan terhadap penggunaan. 
Mengingat nilai estimate tersebut bertanda positif, ini berarti bahwa terdapat hubungan yang searah antara kualitas layanan dengan penggunaan, yaitu semakin tinggi kualitas layanan yang disediakan sistem e-learning maka akan menyebabkan semakin tinggi pula tingkat penggunaan sistem $e$-learning.

Temuan penelitian ini mengkonfirmasi dan memperluas penelitian yang dilakukan oleh Wang (2007) meneliti kesuksesan e-commence di Taiwan dan Wang dan Liao, (2007) meneliti kesuksesan e-Goverment di Taiwan. Kedua penelitian tersebut menunjukkan hubungan positif signifikan antara kualitas pelayanan dengan penggunaan sistem. Hubungan positif kedua penelitian tersebut dapat terjadi karena penelitian dilakukan pada lingkungan sistem sebagai pendukung pelayanan yang diberikan.

Temuan penelitian ini mengkonfirmasi dan memperluas teori dari Parasuraman et al, (1985) yang menyatakan bahwa kualitas jasa adalah perbandingan antara kualitas jasa yang dirasakan oleh pengguna dengan kualitas yang seharusnya disediakan oleh departemen informasi. Ia menyatakan bahwa kualitas jasa tergantung atas perbedaan antara pelayanan yang diekspektasikan dengan yang dirasakan. Jika ekspektasi pelayanan lebih tinggi dibandingkan dengan yang dirasakan maka dapat dikatakan bahwa pelayanan tersebut tidak memuaskan. Jika ekspektasinya lebih rendah dibanding yang dirasakan maka dapat dikatakan bahwa kualitas jasa berada pada tingkat yang memuaskan.

Temuan penelitian ini juga mengkonfirmasi dan memperluas penelitian yang dilakukan oleh: Kositanurit (2006), Halawi et al. (2007), Petter dan McLean (2009). Petter dan McLean (2009) melakukan penelitian meta-analisis menggunakan DeLone dan Mclean (2003) model, untuk menentukan apakah model telah divalidasi oleh studi penelitian terdahulu. Hasil penelitian Petter dan McLean (2009) adalah: terjadi hubungan yang kuat antara variabel: user satisfaction dan intention to use, net benefits dan intention to use, system quality dan user satisfaction, user satisfaction dan net benefits, information quality dan user satisfaction, information quality dan intention to use, serta system quality dan intention to use; serta terjadi hubungan yang moderate antara information quality dan use, use dan individual impact, serta system quality dan use.

\section{PENUTUP}

Simpulan. Penelitian ini bertujuan menyelidiki pengaruh kualitas sistem, kualitas informasi, kualitas layanan, terhadap kepuasan pengguna sistem e-learning berbasis website di Program Studi Magister Manajemen UMB. Adapun kesimpulan yang dapat dihasilkan adalah sebagai berikut: (1) Semakin baik persepsi kualitas sistem akan semakin meningkatkan penggunaan sistem e-learning. Temuan ini mengkonfirmasi penelitianpenelitian sebelumnya yang menyatakan bahwa kualitas sistem berpengaruh signifikan terhadap penggunaan; (2) Semakin baik persepsi kualitas informasi akan semakin meningkatkan penggunaan sistem e-learning. Temuan ini mengkonfirmasi penelitianpenelitian sebelumnya yang menyatakan bahwa kualitas informasi berpengaruh signifikan terhadap penggunaan. Temuan ini mengkonfirmasi salah satu teori dari Barnes dan Vidgen, 2003 yang menyatakan bahwa kualitas informasi dapat dilihat dengan adanya potensi menghasilkan informasi yang tidak terbatas, baik dalam organisasi maupun diluar organisasi. Walaupun terjadi hubungan yang signifikan, rata-rata jawaban responden untuk kelima indikator masih cenderung kurang baik sehingga masih diperlukan upaya peningkatan kualitas informasi terutama dalam hal: ketepatan waktu dalam penyajian informasi, peningkatan design sistem e-learning, dan keakuratan penilaian kuis dalam 
sistem e-learning; dan (3) Semakin baik persepsi kualitas layanan akan semakin meningkatkan penggunaan sistem e-learning. Temuan ini mengkonfirmasi penelitianpenelitian sebelumnya yang menyatakan bahwa kualitas layanan berpengaruh signifikan terhadap penggunaan. Indikator "jaminan" (kecepatan download materi perkuliahan) memiliki nilai weight terbesar sehingga merupakan indikator yang paling kuat sebagai pengukur variabel kualitas layanan.

Implikasi Manajerial. Pembelajaran dengan sistem e-learning merupakan pengerapan dan pengayaan model pembelajaran dengan menggunakan sistem online yang tidak terbatas terhadap tempat, ruang, dan waktu. Pembelajaran dengan sistem e-learning masih tergolong baru, sehingga penyelenggara sistem e-learning lebih meningkatkan kualitas sistem, kualitas informasi, dan kualitas layanan untuk meningkatkan tingkat penggunaan yang lebih baik dan nyaman. Beberapa hal yang disarankan: (1) untuk meningkatkan kualitas sistem untuk meningkatkan penggunaan sistem e-learning adalah: sistem elearning menyediakan panduan yang mudah dipahami, sistem e-learning menyajikan materi sesuai dengan kebutuhan pembelajaran, sistem e-learning menunjang proses pembelajaran, sistem e-learning mudah dioperasikan, sistem e-learning membuat komunikasi antara pengajar dan mahasiswa lebih intensif, serta kemudahan dalam mengakses fitur sistem e-learning. Sebaliknya ketika sistem e-learning yang disediakan oleh perguruan tinggi mempunyai kualitas sistem yang rendah maka akan berpengaruh dengan rendahnya tingkat penggunaan; (2) untuk meningkatkan kualitas informasi dengan cara: adanya kejelasan informasi tentang meteri perkuliahan pada sistem e-learning, adanya kerincian informasi mengenai materi perkuliahan pada e-learning, adanya ketepatan waktu dalam penyajian informasi, dan sistem e-learning memberikan penilaian yang akurat; dan (3) untuk meningkatkan kualitas layanan dengan cara: proses download materi perkuliahan berlangsung dengan cepat, penialian hasil pembelajaran online setara dengan perkuliaha konvensional, dan unit pengelola mudah dihubungi saat pengguna menemui masalah dalam akses ke sistem e-learning. Sebaliknya ketika kualitas layanan semakin rendah maka semakin rendah pula tingkat penggunaannya.

Saran untuk Penelitian Selanjutnya. Saran yang dapat diberikan bagi peneliti selanjutnya berdasarkan keterbatasan penelitian yang ada adalah: (1) pada penelitian selanjutnya diharapkan dapat diterapkan pada kategori penggunaan e-service dalam bidang bisnis, misalnya: e-procurement, e-shopping, dan e-banking. (2) Untuk penelitian selanjutnya disarankan pada penggunaan variabel lain dalam teori pembelajaran sosial.

\section{DAFTAR RUJUKAN}

Bailey, J.E. and Pearson, S.W. (1983) Development of a Tool for Measuring and Analyzing Computer User Satisfaction, Management Science (29:5), May 1983, 530545.

Davis, Fred D., (1989) "Perceived Usefulness, Perceived Ease of Use, and User Acceptance of Information Technology", MIS Quarterly, September, 319- 340

Davis, Fred D., Bagozzi, Richard P., dan Warshaw, Paul R., (1989) "U ser Acceptance Of Computer Technology: A Comparison Two Theoretical Models" Management Science, August, 982-1003

DeLone, W.H., and McLean E.R, (1992) "Information System Success: The Quest for the Dependent Variable" . Information System Research, March, 60-95. 
(2003) "The Delone and Mclean Model of Information Systems Success: A Ten-Year Update," Journal of Management Information Systems, 19 (4), 9-30.

. (2004) Measuring E-commerce Success: Applying the DeLone and McLean Information System Success Model, International Journal of Electronic Commerce.

Doll, William dan Xiadong Deng. (2001) "The Collaborative Use Of Information Technology: End User Participation and System Success". Information Resources Management Journals. ABI/INFORM Global.

Doll, W.J., and Torkzadeh, G. (1991) "Issues and Opinions-The Measurement of EndUser Computing Satisfaction: Theoretical and Methodological Issues," MIS Quarterly, 15, 1991, 5-10.

--------. (1988) "The Measurement of End User Computing Satisfaction", MIS Quarterly, 12, (2), 159-174.

Doll W.J., Xia W., and Torkzadeh G. (1994) “A Confirmatory Factor Analysis of The End-User Computing Satisfaction Instrument" . MIS Quarterly 18(4), 453-461.

Engelbrecht, E. (2003) A Look at E-Learning Models: Investigating Their Value for Developing an E-Learning Strategy. University of Pretoria Bureau for Learning Development, Unisa Progressio.

Gable, G., Sedera, D., \& Chan, T. (2008) "Re-conceptualizing Information System Success: The IS-Impact Measurement Model". Journal of the Association for Information Systems, 9(7), 377-408.

Guimaraes, T., and Igbaria, M. (1997) "Client/Server System Success: Exploring the Human Side", Decision Sciences, (28), 851-876.

Guimaraes, T., M. Igbaria, and M. Lu. (1992) "The determinants of DSS success: An integrated model". Decision Sciences, 23 (2), 409-430.

Guimaraes, T., D. S. Staples, dan J. D. McKeen, (2003) "Empirically Testing Some Main User-Related Factor for Systems Development Quality". Quality Management Journal, 10 (4), 39- 54.

Ho, W. (2004) "Use of Information Technology and Music Learning in the Search for Quality Education". British Journal of Educational Technology, 35 (1), 57-67.

Holsapple, C., and Lee-Post A., (2006) "Defining, Assessing, and Promoting E-Learning Success: An Information Systems Perspective Decision Sciences”, Journal of Innovative Education, 4 (1), Printed in the U.S.A.

Hsu D., Karampatziakis N., Langford J., and Smola A,. (2011) Parallel online learning. In Scaling Up Machine Learning.

Igbaria, M., and Tan, M. 1997. "The Consequences of Information Technology Acceptance on Subsequent Individual Performance," Information \& management (32:3), pp 113121.

Igbaria, M., Livari,.J., \& Maragahh, H.(1995) "Why do individuals use computer technology? A Finnish case study". Information \& Management, 29, 227-23

Ives B, Olson M and Baroudi JJ (1983) "The Measurement of User Information Satisfaction". Communications of the ACM, 26(10), 785-793.

Jenkins, M. dan Hanson, J., (2003) "e-Learning Series: A guide for Senior Managers", Learning and Teaching Support Network (LTSN) Generic Centre, United Kingdom, August 2003.

Kamali, S.B Kan, M. Bashir, A.B. Khan. (2009) "Motivation and Its Impact on Job Performance", European Journal of Work and Organizational Psychology, 17 (2). 
Khan, B. H. (2005) E-Learning QUICK Checklist. Hershey, PA: Information Science Publishing.

Kelley, H. (2001) "Attributional Analysis of Computer Self-efficacy," PhD Dissertation, The University of Western Ontario

Kheterpal, S., (2005) Quality Measures in Design \& Development of e-Learning Content (Sumber:http://elearn.cdac.in/eSikshak/eleltechIndia05/PDF/26Quality\%20Measures \%20in\%20Design\%20\&\%20Development\%20of\%20eLearning\%20Co

Lee, H. (2006) Promoting the knowledge-based economy through e-Learning. In Kim, J.(Ed.) New paradigms of human resources development. Seoul: Korea Research Institute for Vocational Education and Training (KRIVET).

Lee Y., Strong D., Kahn B., Wang R. Y., (2002) “AIMQ: A Methodology for Information Quality Assessment", Information and Management, 40 (2), 133-146.

Lee-Post, A. (2009) "e-Learning Success Model: an Information Systems Perspective". Electronic Journal of e-Learning, 7(1), 61-70.

Lending, D. \& Dillon, T. (2007) "The Effects of Confidentiality on Nursing Self-Efficacy with Information Systems". International Journal of Healthcare Information Systems and Informatics, 2 (3), 49-64.

Planning and Action Research. Human Relations, 1(2), 143-153.

Lewis, D.E., (2002) More Companies Seeing Benefits of E-Learning. A Departure From Training by The Book. The Boston Globe, Globe Staff. (Sumber: http://bostonworks.boston.com/globe/articles/052602/elearn.html)

Lin, H.-F. (2007) "Measuring online learning systems success: Applying the updated DeLone and McLean model". CyberPsychology and Behavior, 10 (6), 817-820.

Liu C and Arnett KP (2000) "Exploring The Factors Associated With Web Site Success In The Context Of Electronic Commerce" . Information and Management, 38(1), 2333.

Livari,Juhani, (2005) "An Empirical Test of the DeLone and McLean Model of Information System Success", Database for Advances in Information Systems, Spring,, 36,2.pg.8.

McGill, Tanya, Hobbs, Valerie, dan Klobas, Jane, (2003) "User-Developed Applications and Information Systems Success: a Test of DeLone and McLean's Model", Information resource Management Journal; Jan-Mar; 16 (1) 24.

McKeen JD, Guimaraes T and Wetherbe JC (1994) "The Relationship Between User Participation And User Satisfaction: An Investigation Of Four Contingency Factors". MIS Quarterly 18(4), 427-451.

McKeen J. D., Guimaraes, T., dan D. S. Staples. (2003) "Empirically Testing Some Main User-Related Factor for Systems Development Quality, Quality" Management Journal, 10(4), 39- 54.

McKiney, V., Yoon, K., and Zahedi, Fatemeh, (2002) "The Measurement of WebCustomer Satisfaction: An Expectation and Disconfirmation Approach", Information System Research, 13,3.

Nielsen J. (2000) Designing Web Usability. Indiana USA: New Riders.

Oliver LW (1987) Research integration for psychologists: an overview of approaches. Journal of Applied Social Psychology 17(10), 860-874.

Palmer, J. W. (2002) "Web Site Usability, Design, and Performance Metrics". Information Systems Research, 13(2), 151-167. 
Parasuraman, A., (2000) “Technology Readiness Index (TRI): A Multiple Item Scale to Measure Readiness to Embrace New Technologies", Journal of Service Research.

Pitt, L., Watson, R., dan Kavan, B. (1998) "Measuring Information Systems Service Quality: Lessons from Two Longitudinal Case Studies". MIS Quarterly, 22(1), 6179.

Seddon, P.B., and Yip, S-K. (1992) "An Empirical Evaluation of User Information Satisfaction (UIS) Measures for Use with General Ledger Accounting Software", Journal of Information Systems Spring, 75-92.

Seddon.P.B. (1997) "A Respecification and Extension of The DeLone and McLean's Model of IS Success", Information System Research.8.September. 240-250.

Seddon, P. B., and Kiew, M.Y. (1996) "A Partial Test and Development of DeLone and MacLean's Model of IS Success." Australian Journal of Information Systems, 4(1).

Solimun. (2012) "Investigation the Instrument Validity: Concistensy between Criterion Validity and Unidimensional Validity". $2^{\text {nd }}$ Basic Science International Conference 2012. February $24-25^{\text {th }}$ Aria Hotel Malang Indonesia.

Subramanian, Girish. H. (2005) "An Empirical Application of the DeLone and McLean Model in The Kuwaiti Private Sector." Journal of Computer Information Systems.

Umar, H., (1999) Metode Penelitian Untuk Skripsi dan Tesis Bisnis, Penerbit PT Raja Grafindo Persada, Cetakan II, Jakarta.

- (2003) Metode Riset Perilaku Organisasi. Jakarta: Gramedia.

Venkatesh, V. (2000) "Determinants Of Perceived Ease Of Use: Integrating Control, Intrinsic Motivation, And Emotion Into The Technology Acceptance Model". Information System Research, 11 (4), 342-365.

Venkatesh, V., dan Davis, F. D. (1996) A Model Of The Antecedents Of Perceived Ease Of Use: Development and Test. Decision Sciences, 27(3), 451

Venkatesh, V., Morris, M. G., Davis, G. B., \& Davis, F. D. (2003) "User Acceptance of Information Technology: Toward a Unified View" . MIS Quarterly, 27 (3), 425478.

Wang Y. (2007) "Assessing e-commerce Systems Success: A Respecification and Validation of the DeLone and McLean model of IS success," Blackwell Publishing Ltd, Information Systems Journal, 1-29

Wang, Yi-Shun dan Liao, Yi-Wen (2007) "Assessing e-Government systems success: A validation of the DeLone and McLean Model of Information Systems Success," Government Information Quarterly, 1-17

Wang, R., dan Strong, D., (1996) Beyond Accuracy: What Data Quality Means to Data Consumers, Journal of Management Information Systems, 4, pp.5-34.

Watson, R., Pitt, L., dan Kavan, B. (1998) Measuring Information Systems Service Quality: Lessons from Two Longitudinal Case Studies. MIS Quarterly, 22(1), 61-79.

Zeithaml, V., Berry, L. dan Parasuraman, A., (1996) "The behavioral consequences of service quality", Journal of Marketing, Vol. 60, April, 31-46.

Zeithaml, V.A., Parasuraman, A. and Berry, L.L. (1990) Delivering quality service; Balancing customer perceptions and expectations, The Free Press, New York, NY.

Zikmund, William. G. (2003) Exploring Marketing Research $8_{\text {th }}$ Edition. USA, Ohio: South Western, A Division of Thomson Learning.

Zmud, W. (1984) "Design alternatives for organizing information systems activities" . MIS Quarterly, 8(2), 79-93. 